\section{Oxford Training Course on Tropical Moist-forest Resources Management and Conservation}

Tropical moist-forest is a useful term to describe tropical rain-forests plus tropical seasonal (usually monsoon) forests, which are the closed, woody-vegetation types of perhumid and seasonally (but not excessively) dry tropical climates. These forests cover great tracts of the equatorial belt and, until not long ago, seemed virtually inexhaustible. But over the last two to three decades their exploitation has increased, and now it is widely realized that they are of finite extent, so that there is a real prospect of their exhaustion within the life-time of people now living.

Tropical moist-forests are a very valuable natural resource in many tropical countries, where the rain-forests provide timber for export, either as logs or as sawn timber and plywood-so constituting a principal source of national income in several countries. Tropical monsoon forests are also being heavily exploited-in this case mainly for fuel-wood to supply the rapidly increasing population both locally and in expanding urban areas.

There is always a conflict between the short-term gain obtained by immediate exploitation, which is sometimes followed by conversion of the land to agriculture (plantations, arable, or pasture), and the longer-term benefits which are less immediately obvious but also of great importance. Forests ameliorate climate, control water runoff rate, and minimize erosion. With careful exploitation and silvicultural treatment, they can be a sustained source of timber and much more. Thus they contain many actual and potential drug-plants and the wild relatives of many fruit-trees. They also contain many unexploited species that are able to contribute to human welfare, as the needs of mankind change in a world which is running short of fossil fuels. Countries with tropical moist-forest are aware of the competing short- and longterm pressures. They are already grappling with the problems in planning the use of their natural resources.

The Commonwealth Forestry Institute, located at Oxford University, has long been involved in tropical forestry. The focus is in the Unit of Tropical Silviculture, a group within the Institute which has active collaboration with practically all parts of the tropics. The Unit is now offering a training course on tropical moist-forest resources and their management and conservation. The course is aimed to set land-use planning and forest management in the context of conservation for the sustained use of natural resources, and to explore the ways in which these different objectives can be reconciled. It is expected that the course will be useful to people with several years' experience in planning and management in a conservation context, most of whom are likely to have a diploma in a different aspect of forestry or in another suitable subject.

The course will draw on the different fields of expertise of the staff of the Commonwealth Forestry Institute. These cover conservation planning (M.E.D. Poore), management (R.A. Plumtre and P.J. Wood), and the plant and vegetation resources (B.T. Styles and T.C. Whitmore). Other contributors from outside the Institute will include G. Lucas and A. Mence (on IUCN-recognized threatened species and their monitoring), M.J. Coe and Lord Cranbrook (on pertinent animals), and P.F. Burgess (on sustained-use forest management).

Teaching will be by lectures, seminars, and workshops, and will include detailed case-studies prepared and presented by participants. There will also be visits to institutes concerned with resource utilization and conservation (Royal Botanic Gardens, Kew; Birmingham University, for genetic resource conservation; and the Forest Products Labouratory, Princes Risborough). The course will include a tour-in collaboration with the UK Nature Conservation Council-which will demonstrate several British examples of land-use management and conservation.

The course is planned to run for the nearly 6 weeks of 17 October to 26 November 1983, and has still some places vacant. Further details may be obtained from $\mathrm{Mr}$ P.D. Hardcastle, Course Organizer, at the address given below:

\author{
TIMOTHY C. WhitMore \\ Joint Course Organizer \\ Commonwealth Forestry Institute \\ University of $O x f o r d$ \\ South Parks Road \\ Oxford $O X I 3 R B$ \\ England, $U K$.
}

\section{Environmental Aspects of the Law of the Sea Treaty}

The Convention on the Law of the Sea will create an important international framework for the protection and conservation of the marine environment and its resources. It contains a number of legal obligations of major environmental significance, including the fundamental obligation of State signatories to protect and preserve the marine environment.

States would be bound by the Convention to use the best practical means at their disposal to prevent and control marine pollution from any source, and would be liable for damage caused by violation of their international obligations to combat marine pollution. They would be bound to cooperate both globally and regionally to formulate additional rules and technical standards of environmental protection, and would commit themselves to promote technical assistance for developing countries in this area of concern. In addition, the Convention would bind States to adopt measures to manage and conserve living resources, especially emphasizing the conservation, management, and study, of cetaceans. The Convention would provide an innovative system of resolving ocean-related disputes, including binding international settlement of applicable environmental disputes.

In recent Congressional testimony, the Sierra Club and other environmental organizations stated: 'Although the current draft Convention is not perfect... we can say without reservation that widespread acceptance and implementation of the Convention's environmental provisions are fundamental to the preservation of the marine environment.'

At the May 1982 meeting of the Sierra Club Board of Directors, the Club hailed the treaty as 'a historic step... 
requiring nations to conserve and protect the marine environment', and urged President Reagan to 'sign the treaty and seek its ratification'. In the same resolution the Sierra Club also called upon all nations to protect the marine environment, as urged by the World Conservation Strategy.*

ANITA YURCHYSHYN, Chairman

Sierra Club International Marine Environment Committee International Earthcare Center

228 East 45 Street

New York, NY 10017, USA.

\section{The Woodlands Conference and the Mitchell Prize Competition}

The Woodlands Conference, Inc., was founded in 1975 as a non-profit educational institution for the purpose of public education concerning the issues of sustainable societies. The term 'sustainable societies' means, in this context, societies in which social and economic progress has been made that is consistent with the world's finite resource-base; in other words, societies which are not necessarily dependent on continued growth in energyuse, population, materials consumption, and industrial output.

The Conference as a whole is engaged in a 10-15years' series of biennial conferences, the next of which, entitled 'The Future and the Private Sector', is to be held during 7-10 November 1982 near Houston, Texas. The conference will consider the major factors of production in the context of sustainable societies over the next two decades, and will involve several hundred business, academic, governmental, and non-governmental, leaders from around the world.

Associated with each biennial event is the Mitchell Prize competition for scholarly papers on the means and possibilities of transition to sustainable societies. The theme for this year's $\$ 100,000$ competition is 'Future Roles for the Private Sector'. The Woodlands Conference, Inc., also provides speakers occasionally for public events, and publishes a quarterly newsletter Sustainable Societies.

The Woodlands Conference, Inc., receives most of its financing from the Mitchell Energy and Development Corp, and from George and Cynthia Mitchell who sponsor the Mitchell Prize. Dr Gerald O. Barney, previously Study Director of The Global 2000 Report to the President, is executive director of the Woodlands Conference. For further information write: The Woodlands Conference, Inc., PO Box 9663, Arlington, Virginia 22209, USA.

\section{Study to Understand how Earthquakes Originate and Behave}

The United States and India are moving swiftly to install a network of instruments to measure earthquake

\footnotetext{
*Nevertheless on 9 July 1982 President Reagan announced that the United States would not sign the Treaty; for although they recognized that it contains 'many positive and very significant accomplishments' and that 'most other provisions are consistent with US interests', the Administration rejected the deep seabed mining portions of the text.-Ed.
}

ground-motion in northern India, which is one of the world's areas where large earthquakes are 'common'.* Fifty accelerographs-instruments that measure strong ground-motion-will be installed in the initial stage of the two-years' project in the Himalayan region. The network could eventually be increased to 200 instruments.

The US National Science Foundation is coordinating the project with the Indian Department of Science and Technology, through the University of Roorkee.

The Indian array, one of a series of such networks that are planned throughout the world, is designed to help to provide a comprehensive set of strong ground-motion data from near the centre of destructive earthquakes. The data are urgently needed by earthquake engineers whose research has been handicapped by a lack of such information. Specifically, the project will gather data on how earthquakes originate, how ground-motion is transmitted, and how it changes in intensity.

C. Eric Lindvall, of Lindvall, Richter \& Associates, an earthquake sciences and engineering firm in Los Angeles, is principal investigator for the US. Lindvall stated that in 1978 an international group of engineers and scientists identified 28 regions of the Earth as likely to have large earthquakes in the 'next decade or so'. These were considered good locations for installing the strong-motion instruments. Four of these 28 sites had experienced a strong earthquake in recent years, he said, which 'makes it urgent that this area should be instrumented promptly and adequately so as to record the strong groundmotions which would be generated by the probable large earthquake in the region'.

In the past century there have been several Himalayan earthquakes that can be counted as among the largest in history. Lindvall said: 'The occurrence of a large earthquake in the region can thus be expected in the present or coming decades.'

The advantages of joint research to both the US and India were pointed out by Lindvall: 'For the US... the increase in potential availability of data concerning large earthquakes from a highly seismic region would represent a very significant addition to the capabilities of existing US networks. For India, the experience gained in operation of large field arrays and instrumentation and in the large-scale data processing requirements of such arrays would be most valuable.'

A committee that will work with Lindvall includes Dr Anil K. Chopra of the University of California-Berkeley; Dr Donald E. Hudson, University of Southern California, and Dr Haresh C. Shah of Stanford University. The Himalayan area was designated as the site for the array after two meetings: the International Workshop on Strong-Motion Earthquake Instrument Arrays, held in Hawaii in May, 1978, and the Indo-US Workshop on Natural Disaster Mitigation Research in New Delhi in December, 1978.

RALPH KAZARIAN
National Science Foundation
1800 G Street
Washington
DC 20550, USA.

* Others of course include the Tokyo and San Francisco areas respectively on the western and eastern Pacific Ocean coasts, and, perhaps still more alarmingly, the New Madrid area in the 'middle eastern' United States-see the 'new nightmare' account in The Economist, 4 September 1982, pp. 93-4, with map indicating also nuclear power-plants.-Ed. 